\title{
Initial and Follow-up Results of the BiodivYsio Phosphorylcholine Coated Stent for Treatment of Coronary Artery Disease
}

\author{
Norihiko Shinozaki, MD; Hiroyoshi Yokoi, MD; Masashi Iwabuchi, MD; \\ Hideyuki Nosaka, MD; Kazushige Kadota, MD*; \\ Kazuaki Mitsudo, MD*; Masakiyo Nobuyoshi, MD
}

\begin{abstract}
Background The BiodivYsio stent is coated with a phosphorylcholine containing copolymer to confer biocompatibility. The present study was designed to assess the safety and efficacy of this coronary stent for the treatment of native coronary artery lesions in patients with coronary artery disease.

Methods and Results From August 2001 to April 2003, 130 patients with lesions were treated with this stent. Elective stenting (ES) was performed in 90 patients and bailout stenting (BS) was performed in 40 patients with small vessels. Pre-interventional reference diameter, minimal lumen diameter (MLD), and lesion length were $2.68 \pm 0.51,1.00 \pm 0.30,12.78 \pm 4.32$, respectively, and post-interventional MLD was $2.24 \pm 0.45 \mathrm{~mm}$. The initial success rate was $100 \%$. However, 2 non-Q-wave myocardial infarctions (non-QMI) occurred post-procedurally due to branch occlusion. A 6-month follow-up was performed. No subacute thrombosis occurred. In the ES group, 1 non-QMI occurred after the interventional procedure in another vessel. There was no death or coronary artery bypass grafting $(\mathrm{CABG})$. The angiographic restenosis rate was $15.6 \%$. In the BS group, there was no death, myocardial infarction or CABG. The angiographic restenosis rate was $17.5 \%$.

Conclusion The BiodivYsio stent is safe and effective as a primary device for the treatment of native coronary artery lesions, especially in small vessels. (Circ J 2005; 69: 295-300)
\end{abstract}

Key Words: BiodivYsio stent; Coronary artery disease; Coronary stent; Percutaneous coronary intervention; Phosphorylcholine

$\mathbf{T}$ he use of coronary stents for the treatment of stenotic coronary artery disease has increased markedly in the last several years. Coronary stents have improved both the short and long-term clinical outcomes of percutaneous coronary intervention.,2 Nevertheless, the risk of subacute thrombosis and the incidence of in-stent restenosis remains the major limitations of coronary stent implantation. A number of strategies have been adopted in an effort to reduce those risks ${ }^{3-5}$ Stent-based approaches include the attachment of anti-coagulants such as heparin ${ }^{6}$ or the use of radioactive stents ${ }^{7}$ to reduce local cell proliferation. Simply coating stents with biocompatible polymers to mask the underlying thrombotic metal surface is another approach. Earlier studies on stents coated with a variety of biodegradable and biostable polymers showed marked inflammatory responses and subsequent neointimal thickening8. However, both in vitro and in vivo research have demonstrated that phosphorylcholine (PC)-based polymers are effective in improving the biocompatibility of inert materials9-11 Phosphorylcholine is a major component of the outer layer head-groups of the cell membrane. These characteristics lend themselves to the application of this

(Received July 26, 2004; revised manuscript received December 6, 2004; accepted January 6, 2005)

Department of Cardiology, Kokura Memorial Hospital, Kitakyushu, *Department of Cardiology, Kurashiki Central Hospital, Kurashiki, Japan

Mailing address: Norihiko Shinozaki, MD, Department of Cardiology, Kokura Memorial Hospital, 1-1 Kifune-machi, Kokurakita-ku, Kitakyushu 802-8555, Japan. E-mail: kmhptca@nn.iij4u.or.jp material as a biocompatible coating for stents.

The BiodivYsio stent is characterized by a combination of this PC-based coating with a unique stent design. Therefore, we expect this stent to reduce the risk of subacute thrombosis and the incidence of in-stent restenosis.

The present study was designed to assess the safety and efficacy of this coronary stent for the treatment of native coronary artery lesions in patients with coronary artery disease in 2 cardiac catheterization laboratories. This is the first clinical trial using the BiodivYsio stent in Japan.

\section{Methods}

\section{Study Population}

This prospective trial was performed at 2 cardiac catheterization laboratories in Japan and included 130 patients with documented myocardial ischemia. Inclusion criteria included: (i) patient at least 20 years old; and (ii) the patient agreeing to a 6-month clinical and angiographic follow-up. Written informed consent to participate in the current study was obtained from all patients.

Patients were excluded according to the following criteria: unprotected left main coronary disease, left ventricular ejection fraction $<30 \%$, recent acute myocardial infarction (AMI) within 7 days, histories of cerebrovascular accident or transient ischemic attack within the previous 1 year, history of gastrointestinal bleeding within 6 months, contraindication to aspirin or ticlopidine, or pregnancy. 
Table 1 Baseline Clinical Characteristics of the Study Population

\begin{tabular}{lccc}
\hline \hline & All patients & Open cell & Small vessel \\
\hline No. of patients & 130 & 90 & 40 \\
Male & $101(77.7 \%)$ & $76(84.4 \%)$ & $25(62.5 \%)$ \\
Age & $67 \pm 10$ & $67 \pm 11$ & $68 \pm 9$ \\
CCS class III/IV & $19(14.8 \%)$ & $14(15.6 \%)$ & $5(12.5 \%)$ \\
Diabetes mellitus & $45(34.6 \%)$ & $25(27.8 \%)$ & $20(50.0 \%)$ \\
Hypertension & $84(64.6 \%)$ & $55(61.1 \%)$ & $29(72.5 \%)$ \\
Hyperlipidemia & $53(40.8 \%)$ & $38(42.2 \%)$ & $15(37.5 \%)$ \\
Smoking & $31(23.8 \%)$ & $25(27.8 \%)$ & $6(15.0 \%)$ \\
\hline
\end{tabular}

CCS, Canadian Cardiovascular Society Functional Classification.

\section{Stent Design}

Two variations of the BiodivYsio PC-coated stent were used in the present study: the open cell type (OC) for vessels $3.0 \mathrm{~mm}$ in diameter or larger, and the small vessel type (SV) for vessels less than $3.0 \mathrm{~mm}$ in diameter. The stent tube diameter before dilatation of the $\mathrm{OC}$ is $1.6 \mathrm{~mm}$ and for the SV it is very small at $1.0 \mathrm{~mm}$. The stent strut thickness of the OC is $91.44 \mu \mathrm{m}$ and for the SV it is very thin at $60.96 \mu \mathrm{m}$. The OC is available in diameters of 3.0, 3.5 , and $4.0 \mathrm{~mm}$ and in lengths of 15,18 , and $28 \mathrm{~mm}$. The $\mathrm{SV}$ is available in diameters of 2.0 and $2.5 \mathrm{~mm}$ and in lengths of 10 and $18 \mathrm{~mm}$.

This stent is a balloon-expandable slotted tube stent laser cut from 316L stainless steel based on an interlocking arrowhead design. Its design enables both maximum longitudinal flexibility and radial strength. Six elements arranged circumferentially permit symmetric expansion. This stent is coated with a PC-containing copolymer to confer biocompatibility.

\section{Stent Implantation}

All patients were premedicated with $100-300 \mathrm{mg}$ of aspirin per day and $200 \mathrm{mg}$ of ticlopidine per day orally for at least $12 \mathrm{~h}$ prior to implantation. Heparin was given intravenously as a bolus dose of 10,000 IU at the beginning of the procedure and later as required to maintain the activated clotting time $>300$ s. Infusion of glycoprotein IIb/IIIa platelet inhibiter was not given to all patients. Intracoronary isosorbide dinitrate $2.5-5.0 \mathrm{mg}$ was administered immediately prior to baseline angiography and at post-stent deployment final angiography.

The procedure was carried out in accordance with standard techniques. After predilatation, the stent was deployed at the treatment site. The choice of angioplasty and stent delivery balloon was made by the operator during the procedure according to a visual assessment of the reference diameter (RD) of the vessel in which the procedure was being carried out. Intravascular ultrasound (IVUS) was not available for the selection of balloon or stent sizes. Procedural success was defined as less than $30 \%$ residual stenosis after stent implantation. After stent implantation, administration of aspirin was continued indefinitely and ticlopidine was prescribed for 28 days in all cases.

\section{Quantitative Coronary Angiographic (QCA) Analysis}

QCA measurements were performed pre-procedurally, post-stent deployment, and at 6-month follow-up by an experienced investigator who was not involved in the angioplasty procedure. QCA analysis was performed using the already validated automated edge detection computer algorithm and commercially available Cardiovascular Angiography Analysis System II! ${ }^{12}$ Each lesion was analyzed
Table 2 Baseline Angiographic Characteristics of the Study Population

\begin{tabular}{lccc}
\hline \hline & $\begin{array}{c}\text { All patients } \\
(\%)\end{array}$ & $\begin{array}{c}\text { Open cell } \\
(\%)\end{array}$ & $\begin{array}{c}\text { Small vessel } \\
(\%)\end{array}$ \\
\hline Restenotic lesion & $10(7.7)$ & $7(7.8)$ & $3(7.5)$ \\
Bifurcation lesion & $31(23.8)$ & $21(23.3)$ & $10(25.0)$ \\
Calcified lesion & $9(6.9)$ & $5(5.6)$ & $4(10.0)$ \\
Tortuous lesion & $31(23.8)$ & $23(25.6)$ & $8(20.0)$ \\
Type B2 & $65(50.0)$ & $48(53.3)$ & $17(42.5)$ \\
Type C & $8(6.2)$ & $7(7.8)$ & $1(2.5)$ \\
LAD & $44(33.8)$ & $30(33.3)$ & $14(35.0)$ \\
LCX & $38(29.2)$ & $20(22.2)$ & $18(45.0)$ \\
RCA & $47(36.2)$ & $40(44.4)$ & $7(17.5)$ \\
HL & $1(0.8)$ & $0(0)$ & $1(2.5)$ \\
\hline
\end{tabular}

Type, Modified American College of Cardiology/American Heart Association criteria; $L A D$, left anterior descending coronary artery; LCX, left circumflex coronary artery; RCA, right coronary artery; $H L$, high lateral coronary branch.

in 2 approximately orthogonal projections selected for maximal avoidance of superimposition and vessel foreshortening. The distal end of the guiding catheter was used for calibration in each analyzed projection. Lesion length, $\mathrm{RD}$, minimal lumen diameter (MLD), percentage diameter stenosis (\%DS) before and after stent implantation and at 6-month follow-up were measured. The stent/artery ratio on QCA was calculated by dividing the maximal diameter of the inflated balloon by the RD. Angiographic restenosis was defined as $>50 \%$ DS at 6-month follow-up angiography at any point within the stented segment or in the $3 \mathrm{~mm}$ proximal or $3 \mathrm{~mm}$ distal to the edge or the nearest side branch. Lesions were characterized according to the modified American College of Cardiology/American Heart Association criteria.

\section{Clinical and Angiographic Follow-up}

All patients were asked to return to have clinical followup studies at 30 days and 6 months after the stent deployment. Coronary angiography was requested to be performed at 6 months in all patients. The endpoint of the present study was the occurrence of any of the following events: acute or subacute stent thrombosis, AMI, repeat coronary intervention, coronary artery bypass grafting (CABG), angiographic restenosis at 6 months, or death.

\section{Statistical Analysis}

Continuous variables are expressed as means \pm standard deviation. Discrete variables are expressed as counts and percentages. Paired student's t-test or Welch's t-test were used for comparisons of each variable. Results were considered statistically significant at $\mathrm{p}<0.05$.

\section{Results}

\section{Baseline Data}

From August 2001 to April 2003, 130 patients with lesions were treated with this stent. Table 1 represents the baseline clinical characteristics of the study population. Ninety patients underwent elective stenting and 40 patients underwent bailout stenting of small vessels. There were 101 males and 29 females with a mean age of $67 \pm 10$ years with $35 \%$ of the patients having diabetes mellitus, $65 \%$ with hypertension, $41 \%$ with hyperlipidemia, and $24 \%$ were current smokers. 
Table 3 Implanted Stent Size

\begin{tabular}{cccccc}
\hline \hline & \multicolumn{5}{c}{ Diameter $(\mathrm{mm})$} \\
\cline { 2 - 6 } & 2.0 & 2.5 & 3.0 & 3.5 & 4.0 \\
\hline Length $(\mathrm{mm})$ & & & & & \\
10 & $4(3.1)$ & $16(12.3)$ & - & - & - \\
15 & - & - & $33(25.4)$ & $14(10.8)$ & $3(2.3)$ \\
18 & $6(4.6)$ & $14(10.8)$ & $19(14.6)$ & $9(6.9)$ & $5(3.8)$ \\
28 & - & - & $5(3.8)$ & $2(1.5)$ & - \\
\hline
\end{tabular}

Values in brackets are percentages.

\section{Procedural Results}

Table 2 describes baseline angiographic characteristics for the patients in the current study; $8 \%$ of lesions were restenotic, $24 \%$ were bifurcation lesions, $7 \%$ were calcified, and $24 \%$ were tortuous. More than half of the patients had type B2/C complex lesions. Stent placement was $34 \%$ in the left anterior descending coronary artery, $29 \%$ in the left circumflex coronary artery, $36 \%$ in the right coronary artery, and $1 \%$ in the high lateral coronary branch.

Implanted stent sizes are shown in Table 3 . The majority of OC stents were 3.0 or $3.5 \mathrm{~mm}$ diameter, and 15 or $18 \mathrm{~mm}$ in length with $4.0 \mathrm{~mm}$ diameter stents used at $6.1 \%$, and $28 \mathrm{~mm}$ length stent were used at $5.3 \%$ of the implants. However, the majority of SV stent implants were $2.5 \mathrm{~mm}$ in diameter and those of $2.0 \mathrm{~mm}$ in diameter were used in $7.7 \%$

Procedural success was obtained in $100 \%(130 / 130)$ of patients.

During the hospitalization period, 2 non-Q-wave myocardial infarction (non-QMI) events occurred post-procedurally due to branch occlusion.

\section{Angiographic Results}

Quantitative coronary analysis data are summarized in Table 4. Pre-procedural lesion length was $12.78 \mathrm{~mm}$. The stent/artery ratio was 1.14 . The maximal final balloon inflation pressure was $12.9 \mathrm{~atm}$. Pre-procedural RD was $2.68 \mathrm{~mm}$. It significantly increased to $2.82 \mathrm{~mm}$ post-procedurally $(\mathrm{p}<0.05)$. At the 6-month follow-up, it significantly decreased to $2.37 \mathrm{~mm}(\mathrm{p}<0.01)$. Changes in MLD and \%DS are shown in Fig 1. Post-procedural MLD significantly increased from $1.00 \mathrm{~mm}$ to $2.24 \mathrm{~mm}(\mathrm{p}<0.01)$. At the 6-month follow-up, it significantly decreased to $1.56 \mathrm{~mm}(\mathrm{p}<0.01)$. Post-procedural \%DS significantly decreased from $62.0 \%$ to $20.5 \%$ ( $p<0.01)$. At the 6-month follow-up, it significantly increased to $34.9 \%(\mathrm{p}<0.01)$. Similar changes in both OC and SV stents were observed for MLD and \%DS.

\section{Clinical Follow-up Results}

Clinical follow-up data are presented in Table 5. At the 30-day follow-up, 1 non-QMI event occurred after the interventional procedure in another vessel. No subacute thrombosis was recognized. In the OC stent group, restenosis occurred in $15.6 \%$, target lesion revascularization was performed in $12.2 \%$, and target vessel failure occurred in $13.3 \%$ of the lesions. As mentioned above, 3 non-QMI events occurred. There was no death or CABG. In the SV stent group, restenosis occurred in $17.5 \%$, target lesion revascularization was performed in $15.0 \%$, and target vessel failure occurred in $15.0 \%$ of the lesions. There was no death, myocardial infarction or CABG.

\section{Discussion}

The current study shows that it is feasible to deliver the BiodivYsio stent safely at the target lesion site. Procedural success was obtained in all patients. These observations become increasingly significant when we consider more than half of the patients in the present study had complex coronary anatomies and lesions. We experienced 2 non-QMI patients post-procedurally due to side branch occlusions. Side branches of both cases were small. Therefore, angina and electrocardiographic changes after stent deployment were not remarkable. Side branch access through the stents was not attempted. However, serum creatine kinase levels rose to 648 and $733 \mathrm{IU} / \mathrm{L}$ on the following day, although abnormal Q-waves did not appear.

We experienced no thrombotic events in the current study. Some reports present the experience of the subacute thrombosis,$^{13-17}$ but the rates were equal or lower than previous reports using conventional metallic stents. ${ }^{18}$ The PC polymer mimics the chemical structure of the PC headgroup, which makes up $90 \%$ of phospholipids in the outer membrane of a red blood cell. Phosphorylcholine has been shown to decrease protein absorption and platelet adhesion; thereby we can expect that the PC-coating reduces throm-

Table 4 Quantitative Coronary Angiographic Analysis Data

\begin{tabular}{|c|c|c|c|}
\hline & All patients & Open cell & Small vessel \\
\hline Stent/artery ratio & $1.14 \pm 0.15$ & $1.15 \pm 0.15$ & $1.11 \pm 0.16$ \\
\hline Maximal inflation pressure (atm) & $12.9 \pm 2.9$ & $12.6 \pm 3.0$ & $13.5 \pm 2.7$ \\
\hline \multicolumn{4}{|l|}{ Lesion length $(\mathrm{mm})$} \\
\hline Pre-procedure & $12.78 \pm 4.32$ & $13.15 \pm 4.34$ & $11.91 \pm 4.18$ \\
\hline \multicolumn{4}{|l|}{ Reference diameter $(\mathrm{mm})$} \\
\hline Pre-procedure & $2.68 \pm 0.51$ & $2.88 \pm 0.45$ & $2.21 \pm 0.45$ \\
\hline Post-procedure & $2.82 \pm 0.50 * *$ & $3.04 \pm 0.42 * *$ & $2.33 \pm 0.26$ \\
\hline 6 months & $2.37 \pm 0.50^{\dagger}$ & $2.53 \pm 0.48^{\dagger}$ & $1.99 \pm 0.30^{\dagger}$ \\
\hline \multicolumn{4}{|l|}{ Minimal lumen diameter ( $\mathrm{mm}$ ) } \\
\hline Pre-procedure & $1.00 \pm 0.30$ & $1.08 \pm 0.30$ & $0.82 \pm 0.21$ \\
\hline Post-procedure & $2.24 \pm 0.45 *$ & $2.42 \pm 0.39 *$ & $1.84 \pm 0.26^{*}$ \\
\hline 6 months & $1.56 \pm 0.52^{\dagger}$ & $1.68 \pm 0.54 \dagger$ & $1.27 \pm 0.32^{\dagger}$ \\
\hline \multicolumn{4}{|l|}{ Percent diameter stenosis (\%) } \\
\hline Pre-procedure & $62.0 \pm 7.2$ & $62.0 \pm 7.7$ & $61.9 \pm 5.8$ \\
\hline Post-procedure & $20.5 \pm 5.4 *$ & $20.3 \pm 4.9 *$ & $21.1 \pm 6.4^{*}$ \\
\hline 6 months & $34.9 \pm 13.3^{\dagger}$ & $34.3 \pm 13.6^{\dagger}$ & $36.4 \pm 12.6^{\dagger}$ \\
\hline
\end{tabular}

Values are expressed as mean $\pm S D$.

${ }^{*} p<0.01 ; * * p<0.05$ compared with pre-procedure, ${ }^{\dagger} p<0.01$ compared with post-procedure. 


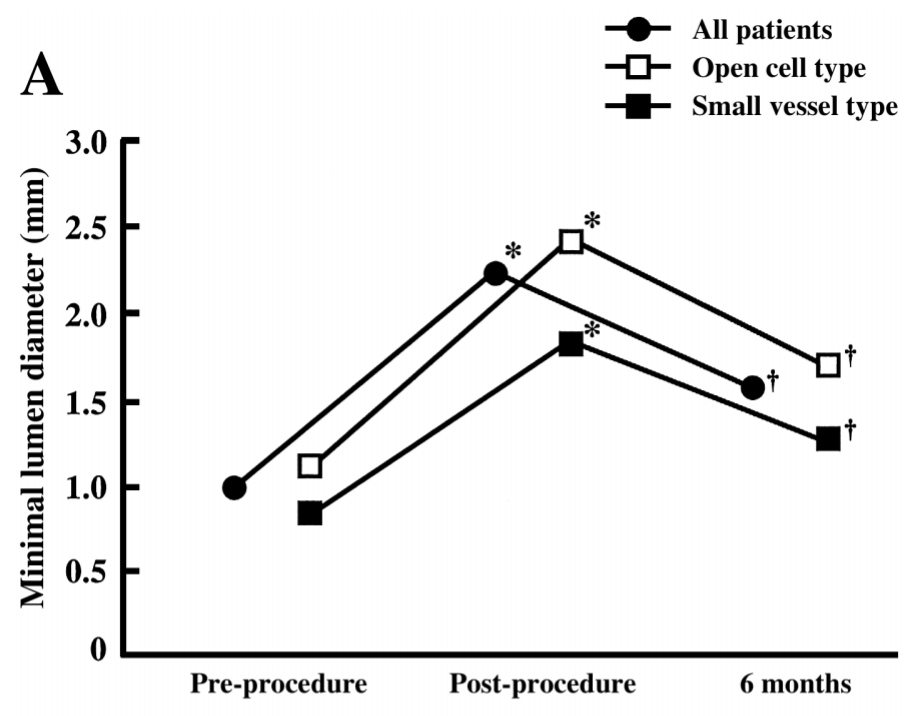

B

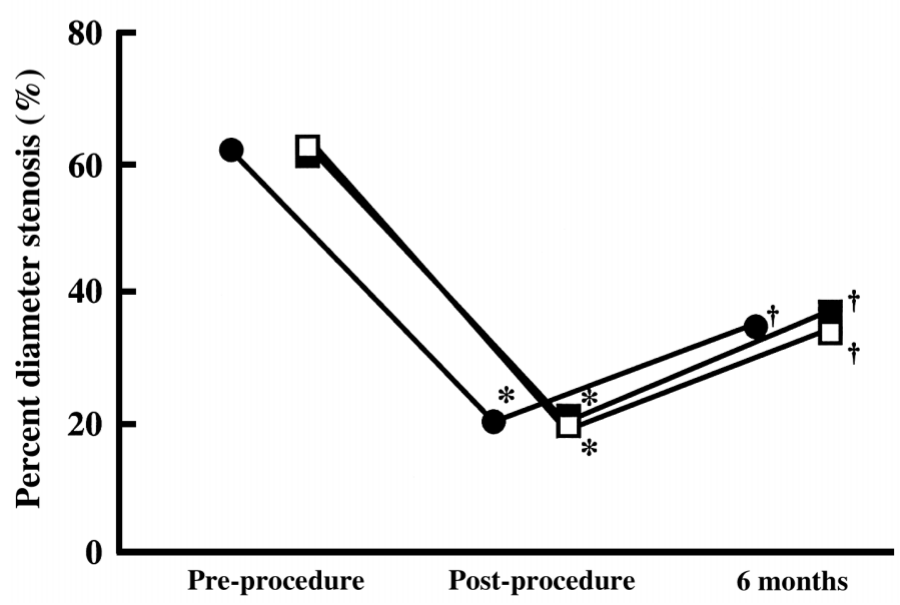

Fig 1. Changes in minimal lumen diameter (A) and percentage diameter stenosis (B) in all patients (closed circle), open cell type (open square) and small vessel type (closed square). ${ }^{*} \mathrm{p}<0.01$ compared with pre-procedure. ${ }^{\dagger} \mathrm{p}<0.01$ compared with post-procedure.
Table 5 Six-Month Clinical Follow-up Data

\begin{tabular}{lccc}
\hline \hline & $\begin{array}{c}\text { All patients } \\
(\%)\end{array}$ & $\begin{array}{c}\text { Open cell } \\
(\%)\end{array}$ & $\begin{array}{c}\text { Small vessel } \\
(\%)\end{array}$ \\
\hline SAT & $0(0)$ & $0(0)$ & $0(0)$ \\
MI & $3(2.3)$ & $3(3.3)$ & $0(0)$ \\
Restenosis & $21(16.2)$ & $14(15.6)$ & $7(17.5)$ \\
TLR & $17(13.1)$ & $11(12.2)$ & $6(15.0)$ \\
TVF & $18(13.8)$ & $12(13.3)$ & $6(15.0)$ \\
MACE & $3(2.3)$ & $3(3.3)$ & $0(0)$ \\
\hline
\end{tabular}

SAT, sub-acute thrombosis; MI, myocardial infarction; TLR, target lesion revascularizasion; TVF, target vessel failure; MACE, major cardiac adverse events.

bus formation of the stainless steel stent, allowing prevention of subacute thrombosis. The results from the current study affirms this hypothesis.

In the present study, patients with AMI were excluded. Galli et al demonstrated that primary stenting of AMI with PC-coated stent leads to excellent short and mid-term clinical outcomes and a low restenosis despite a reduced heparin therapy 19 When we consider, first, that the PCcoated stents reduces thrombogenicity of the stents and second, that acute coronary syndrome (ACS) is strongly affected by thrombus, we might expect better results treat- ing ACS patients with this stent than those with stable angina pectoris. In addition, we may decrease post-procedural bleeding complications because of the short-term heparin regimen or the use of protamine sulfate when we use the PC-coated stents? 20

In the current study, a lower restenosis rate was shown, especially in small vessel lesions. As in previous studies, 16,17 our study shows that the restenosis rate using the BiodivYsio stent in the small vessels is lower than those using any other metallic stents. ${ }^{21-26}$ Moreno et al represented the analysis of 11 randomized trials using conventional metallic stents in small vessels, including angiographic re-evaluation at 6 months. ${ }^{26}$ According to this analysis, the pooled restenosis rate was $25.8 \%$, which was worse than our data, $17.5 \%$. It has been clearly demonstrated that the arterial diameter is one of the most powerful predictors of restenosis; however, in our study, the restenosis rate in lesions of small vessels ( $\leq 2.5 \mathrm{~mm}$ in diameter) were nearly equal to that of lesions in larger vessels $(\geq 3.0 \mathrm{~mm}$ in diameter). Platelet derived growth factor is derived from activated platelet. It accelerates the intimal proliferation. Phosphorylcholine reduces the thrombus formation; therefore, PC might inhibit intimal proliferation and reduce restenosis. The suitability of this stent for small vessels is not only due to the PC-coating. There are few small vessel stents that are specifically 
designed for small diameter vessels. Most of the other small stents are produced with the same stent design as for large vessels mounted on smaller balloons. However, the BiodivYsio SV stent is specifically designed for small vessels and not simply mounted on a smaller balloon. Its diameter before dilatation is $1.0 \mathrm{~mm}$, which is very small, and it has better deliverability than standard stents. Also, the stent strut thickness of the SV is very thin; $60.96 \mu \mathrm{m}$. Considering the previous reports, it is likely thinner struts have some benefits 27,28

Recently, drug-eluting stents (DES) have shown very promising long-term results29,30 Preclinical and clinical studies of DES were shown to be safe and feasible in preventing neointimal hyperplasia, giving rise to a definite decrease in in-stent restenosis. However, small vessel size was shown to significantly increase the incidence of restenosis after sirolimus-eluting stenting in the SIRIUS trial ${ }^{31}$ Moreover, it is difficult to deliver the sirolimus-eluting stent to complex small vessel lesions because of the stent design. As mentioned above, the BiodivYsio SV stent has low restenosis rate and has excellent deliverability. Therefore, if we use the BiodivYsio SV stent as a platform of DES, we might be able to expect better results than what was attained in the SIRIUS trial for small vessels. In addition, DES cannot prevent sudden thrombotic occlusion, so the incidence of subacute stent thrombosis in patients using DES is not different from that with conventional metallic stents: ${ }^{1-34}$ Therefore, the BiodivYsio stent may be useful as a DES platform because PC can decrease thrombus formation. In fact, there are good data of the BiodivYsio dexamethasone-eluting stent $3^{5}$ Moreover, Virmani et al reported the possibility that the hypersensitivity to the polymer of sirolimus-eluting stent can cause late coronary thrombosis ${ }^{36}$ No hypersensitivity reaction to $\mathrm{PC}$ has been reported although the PC polymer has been used for a variety of devices including drain catheters, vascular grafts, artificial hearts, dialysis membrane, and contact lenses. The $\mathrm{PC}$ polymer has excellent biocompatibility. There is a possibility that the BiodivYsio PC-coating stent with drug elution may become the ideal DES because we can expect that the PC-coating prevents sudden thrombotic events and the eluting drug prevents restenosis.

\section{Study Limitations}

The obvious limitation of the current study is that it is an unblinded non-randomized pilot study without a balloon angioplasty or non-coated stent control group. It was performed in a selected small group of patients. Larger prospective randomized studies comparing non-coated stents and longer term follow-up are necessary to determine the essential role of PC-coated coronary stents. In addition, IVUS analysis was not performed in the present study. If we had used IVUS, it might have been helpful to analyze the tissue growth within the stents and to confirm the effect of $\mathrm{PC}$ in inhibiting neointimal tissue proliferation in human coronary arteries.

\section{Conclusion}

The BiodivYsio PC coated stent is safe and effective as a primary device for the treatment of native coronary artery lesions. Of particular interest, the present study showed no thrombotic events and good clinical results in small vessels. Although further studies would be necessary to draw a definitive conclusion, there is a possibility that the
BiodivYsio PC-coating stent will become an ideal platform for DES.

\section{References}

1. Serruys PW, De Jaegere P, Kiemeneij F, Magaya C, Rutsch W, Heyndrickx G, et al. A comparison of balloon-expandable-stent implantation with balloon angioplasty in patients with coronary artery disease. N Engl J Med 1994; 331: 489-495.

2. Fischman DL, Leon MB, Baim DS, Schatz RA, Savage MP, Penn I, et al. A randomized comparison of coronary-stent placement and balloon angioplasty in the treatment of coronary artery disease. $N$ Engl $\mathrm{J}$ Med 1994; 331: 496-501.

3. Gershlick AH, Baron J. Dealing with in-stent restenosis. Heart 1998; 79: $319-323$.

4. Kim KI, Bae J, Kang HJ, Koo BK, Youn TJ, Kim SH, et al. Threeyear clinical follow-up results of intracoronary radiation therapy using a rhenium-188-diethylene-triamine-penta-acetic-acid-filled balloon system. Circ J 2004; 68: 532-537.

5. Suzuki J, Ito H, Gotoh R, Morishita R, Egashira K, Isobe M. Initial clinical cases of the use of a NF- $\kappa \mathrm{B}$ decoy at the site of coronary stenting for the prevention of restenosis. Circ J 2004; 68: 270-271.

6. Hårdhammar PA, van Beusekom HMM, Emanuelsson HU, Hofma $\mathrm{SH}$, Albertsson PA, Verdouw PD, et al. Reduction in thrombotic events with heparin-coated Palmaz-Schatz stents in normal porcine coronary arteries. Circulation 1996; 93: 423-430.

7. Fischell TA, Carter AJ, Laird JR. The beta-particle-emitting radioisotope stent (Isostent): Animal studies and planned clinical trials. Am J Cardiol 1996; 78(Suppl 3A): 45-50.

8. van der Giessen WJ, Lincoff AM, Schwartz RS, van Beusekom MM, Serruys PW, Holmes DR, et al. Marked inflammatory sequelae to implantation of biodegradable and nonbiodegradable polymers in porcine coronary arteries. Circulation 1996; 94: 1690-1697.

9. Whelan DM, van der Giessen, Hrabbendam SC, van Vliet EA, Verdouw PD, Serruys PW, et al. Biocompatibility of phosphorylcholine coated stents in normal porcine coronary arteries. Heart 2000; 83: $338-345$.

10. Malik N, Gunn J, Shepherd L, Crossmann DC, Cumberland DC, Holt CM. Phosphorylcholine-coated stents in porcine coronary arteries: In vivo assessment of biocompatibility. J Invasive Cardiol 2001; 13: $193-201$.

11. Lewis AL, Stratford PW. Phosphorylcholine-coated stents. J Long Term Eff Med Implants 2002; 12: 231-250.

12. Serruys PW, Foley DP, de Feyter PJ editors. Quantitative coronary angiography in clinical practice. Dordrecht: Kluwer Academic; 1994.

13. Zheng H, Barragan P, Corcos T, Siméoni JB, Favereau X, Roquebert $\mathrm{PO}$, et al. Clinical experience with a new biocompatible phosphorylcholine-coated coronary stent. J Invasive Cardiol 1999; 11: 608614.

14. Boland JL, Corbeij HAM, van der Giessen W, Siebra-Gomes R, Suryapranata H, Wijns W, et al. Multicenter evaluation of the phosphorylcholine-coated biodivysio stent in short de novo coronary lesions: The SOPHOS study. Int J Cardiovasc Intervent 2000; 3: $215-225$.

15. Galli M, Bartorelli A, Bedogni F, DeCesare N, Klugmann S, Maiello $\mathrm{L}$, et al. Italian BiodivYsio open registry (BiodivYsio PC-coated stent): Study of clinical outcomes of the implant of a PC-coated coronary stent. J Invasive Cardiol 2000; 12: 452-458.

16. Beaudry Y, Sze S, Fagih B, Constance C, Kwee R. Six-month results of small vessel stenting $(2.0-2.8 \mathrm{~mm})$ with the Biodivysio SV stent. J Invasive Cardiol 2001; 13: 628-631.

17. Grenadier E, Roguin A, Hertz I, Peled B, Boulos M, Nikolsky E, et al. Stenting very small coronary narrowings $(<2 \mathrm{~mm})$ using the biocompatible phosphorylcholine-coated coronary stent. Catheter Cardiovasc Interv 2002; 55: 303-308.

18. Cutlip DE, Baim DS, Ho KKL, Popma JJ, Lansky AJ, Cohen DJ, et al. Stent thrombosis in the modern era: A pooled analysis of multicenter coronary stent clinical trials. Circulation 2001; 103: $1967-$ 1971.

19. Galli M, Sommariva L, Prati F, Zerboni S, Politi A, Bonatti R, et al. Acute and mid-term results of phosphorylcholine-coated stents in primary coronary stenting for acute myocardial infarction. Catheter Cardiovasc Interv 2001; 53: $182-187$.

20. Kuiper KKJ, Nordrehaug JE. Early mobilization after protamine reversal of heparin following implantation of phosphorylcholinecoated stents in totally occluded coronary arteries. Am J Cardiol 2000; 85: 698-702.

21. Savage MP, Fischman DL, Rake R, Leon MB, Schatz RD, Penn I, et 
al. Efficacy of coronary stenting versus balloon angioplasty in small coronary arteries. J Am Coll Cardiol 1998; 31: 307-311.

22. Akiyama T, Moussa I, Reimers B, Ferraro M, Kobayashi Y, Blengino $\mathrm{S}$, et al. Angiographic and clinical outcome following coronary stenting of small vessels: A comparison with coronary stenting of large vessels. J Am Coll Cardiol 1998; 32: 1610-1618.

23. Elezi S, Kastrati A, Neumann FJ, Hadamitzky M, Dirschinger J, Schömig A. Vessel size and long-term outcome after coronary stent placement. Circulation 1998; 98: 1875-1880.

24. Huang P, Levin T, Kabour A, Feldman T. Acute and late outcome after use of 2.5 -mm intracoronary stents in small $(<2.5 \mathrm{~mm})$ coronary arteries. Catheter Cardiovasc Interv 2000; 49: 121-126.

25. Iijima R, Ikari Y, Miyazawa A, Nakajima H, Hara K. Predictors of restenosis after implantation of $2.5 \mathrm{~mm}$ stents in small coronary arteries. Circ J 2004; 68: 236-240.

26. Moreno R, Fernández C, Alfonso F, Hernández R, Pérez-Vizcayno MJ, Escaned J, et al. Coronary stenting versus balloon angioplasty in small vessels: A meta-analysis from 11 randomized studies. $J$ Am Coll Cardiol 2004; 43: 1964-1972.

27. Kastrati A, Mehilli J, Dirschinger J, Dotzer F, Schühlen H, Neumann FJ, et al. Intracoronary stenting and angiographic results: Strut thickness effect on restenosis outcome (ISAR-STEREO) trial. Circulation 2001; 103: 2816-2821.

28. Pache J, Kastrati A, Mehilli J, Schühlen H, Dotzer F, Hausleiter J, et al. Intracoronary stenting and angiographic results: Strut thickness effect on restenosis outcome (ISAR-STEREO-2) trial. J Am Coll Cardiol 2003; 41: $1283-1288$.

29. Holmes DR, Leon MB, Moses JW, Popma JJ, Cutlip D, Fitzgerald PJ, et al. Analysis of 1-year clinical outcomes in the SIRIUS trial: A randomized trial of a sirolimus-eluting stent versus a standard stent in patients at high risk for coronary restenosis. Circulation 2004; 109: 634-640.

30. Stone GW, Ellis SG, Cox DA, Hermiller J, O'Shaughnessy C, Mann JT, et al. One-year clinical results with the slow-release, polymerbased, paclitaxel-eluting TAXUS stent: The TAXUS-IV trial. Circulation 2004; 109: 1942 - 1947.

31. Morice MC, Serruys PW, Sousa JE, Fajadet J, Hayashi EB, Perin M, et al. A randomized comparison of a sirolimus-eluting stent with a standard stent for coronary revascularization. $N$ Engl J Med 2002; 346: $1773-1780$.

32. Schofer J, Schluter M, Gershlick AH, Wijns W, Garcia E, Schampaert E, et al. Sirolimus-eluting stents for treatment of patients with long atherosclerotic lesions in small coronary arteries: Double-blind, randomized controlled trial (E-SIRIUS). Lancet 2003; 362: $1093-$ 1099.

33. Moses JW, Leon MB, Popman JJ, Fitzgerald PJ, Holmes DR, O'Shaughnessy C, et al. Sirolimus-eluting stents versus standard stents in patients with stenosis in a native coronary artery. $N$ Engl $J$ Med 2003; 349: 1315-1323.

34. Jeremias A, Sylvia B, Bridges J, Kirtane AJ, Bigelow B, Pinto DS, et al. Stent thrombosis after successful sirolimus-eluting stent implantation. Circulation 2004; 109: 1930-1932.

35. Liu X, Huang Y, Hanet C, Vandormael M, Legrand V, Dens J, et al. Study of antirestenosis with the BiodivYsio dexamethasone-eluting stent (STRIDE): A first-in-human multicenter pilot trial. Catheter Cardiovasc Interv 2003; 60: $172-178$.

36. Virmani R, Guagliumi G, Farb A, Musumeci G, Grieco N, Motta T, et al. Localized hypersensitivity and late coronary thrombosis secondary to a sirolimus-eluting stent: Should we be cautious? Circulation 2004; 109: 701-705. 